\title{
FOTOGRAFI DALAM DESAIN KOMUNIKASI VISUAL (DKV)
}

\author{
Prayanto Widyo Harsanto \\ FSR Institut Seni Indonesia Yogyakarta \\ E-mail: prayantowh@ymail.com
}

\begin{abstract}
Abstrak
Kebutuhan penggunaan karya fotografi untuk elemen iklan cetak saat ini masih tinggi. Iklan cetak di Indonesia 98\% menggunakan ilustrasi dengan menggunakan teknik fotografi. Serta, pengetahuan dan keterampilan fotografi telah diberikan sebagai mata kuliah wajib di Perguruan Tinggi yang memiliki Program Studi Desain Komunikasi Visual (DKV). Tujuan tulisan ini adalah untuk mengingatkan betapa pentingnya pelajaran fotografi di desain grafis atau DKV, sehingga penting untuk dikelola dengan baik. Selepas tahun 1990-an dunia fotografi mulai memasuki era teknologi digital yang merubah budaya kerja di industri. Dari ketergantungan pada kemampuan skill manual manusia, berubah menjadi serba komputerisasi (digital). Era analog sedikit demi sedikit telah ditinggalkan karena di era digital kegiatan memotret dan paradigma tentang fotografi sudah bergeser. Dunia fotografi dulu dianggap kegiatan yang sulit dan mahal, namun sekarang relatif murah dan mudah. Teknologi boleh berkembang serta paradigma dapat bergeser, tetapi fungsi dan makna pada karya fotografi tetap penting serta diperlukan dalam desain komunikasi visual. Pendidikan Tinggi DKV tentunya ingin menciptakan sumber daya insani yang kompeten pada bidangnya dan diharapkan dapat memberikan kontribusi optimal di lapangan kerja. Alangkah baiknya apabila lembaga pendidikan mempedulikan profesi yang sesuai dengan levelnya.
\end{abstract}

Kata kunci: fotografi, pendidikan DKV, desain komunikasi visual

\section{PHOTOGRAPHY IN VISUAL COMMUNICATION DESIGN}

\begin{abstract}
The need for photography works for printed advertisement is still high. Ninety-eight percents of printed advertisements in Indonesia use illustrations from photography techniques. In addition, the knowledge and skills of photography have been given as compulsory subjects in Higher Education which have a Visual Communication Design Program. The purpose of this paper is to remind us of the importance of photography lessons in graphic design that it is important to be well managed. After the 1990s the world of photography began to enter the age of digital technology that changed the work culture in the industry, from its dependence on human or manual skills into a completely computerized (digital) one. The analogue era has been gradually abandoned because in the digital era photographing activities and the paradigm about photography have shifted. The world of photography was once considered a difficult and expensive activity, but is now relatively cheap and easy. echnology may evolve as well as paradigms may shift, but the function and significance of photography work remain important and necessary in visual communication design. The purpose of a Visual Communication-Design program in Higher Education is to create competent human resources that are able to contribute optimally in the field of work. It would be nice if the educational institutions care about the profession in accordance with the level.
\end{abstract}

Keywords: photography, visual communication design, education 


\section{PENDAHULUAN}

Pada awalnya iklan cetak lebih banyak atau didominasi oleh tulisan dibanding gambar/foto. Namun karena tuntutan pasar, kompetisi, dan perkembangan zaman maka iklan cetak sebagai komunikasi visual mengharuskan untuk tampil memikat. Sekarang foto pada iklan cetak tidak lagi sekadar pendukung teks saja, tetapi menjadi kekuatan dan daya tarik pada suatu iklan. Bahkan ada beberapa iklan yang didominasi dengan ilustrasi foto. Ada beberapa alasan dari pengiklan, yang antara lain mengatakan bahwa dengan menampilkan foto pada iklan maka isi pesan iklan terasa tidak berat bagi pembacanya. Lebih-lebih di era visual seperti saat ini audiens lebih senang melihat visual/ foto yang menarik dibanding banyak tulisannya. Gambar mempunyai kekuatan menarik perhatian secara langsung dan memiliki pengaruh yang besar dalam peran persuasi dari sebuah iklan, dibandingkan iklan yang hanya mengandalkan kekuatan teks (Baker, 1961:57).

Penemuan teknik fotografi oleh Niepce dan Daguerre pada tahun 1839 menjadi penanda bahwa alat ini sangat memungkinkan untuk menggantikan teknik-teknik ilustrasi yang sebelumnya digunakan dalam iklan cetak. Setelah fotografi mulai populer dalam masyarakat dan didukung dengan perkembangan teknologi grafika, maka unsur gambar dengan teknik fotografi banyak digunakan untuk ilustrasi iklan cetak, bahkan mulai menggeser peran gambar tangan sebagai elemen visual dalam iklan. Oleh karena itu, sangat dimungkinkan bahwa kehadiran fotografi dalam iklan menyebabkan berkembangnya kreativitas desainer iklan untuk menciptakan jenis iklan display. Jenis iklan yang memadukan unsur teks dengan gambar (ilustrasi) yang dikomposisikan secara artistik tersebut sering dikatakan sebagai iklan display (pictorial). Dalam iklan display, ilustrasi merupakan bagian dari atau pendamping untuk teks, baik untuk menambah daya tarik visual maupun untuk memperjelas maksud dari teks, sekaligus sebagai alat persuasi yang terkandung dalam pesan iklan. Dalam sebuah riset yang dilakukan oleh majalah Cakram (Februari, 2002) menunjukkan bahwa 98\% ilustrasi iklan pada media massa cetak menggunakan fotografi.

Perkembangan dunia fotografi saat ini sangat cepat dan pesat. Era analog telah sedikit demi sedikit ditinggalkan karena era digital memungkinkan semua orang terlibat. Meskipun demikian, era analog masih memegang peranan penting dalam sejarah fotografi dunia. Kegiatan motret-memotret dan paradigma tentang fotografi memang sudah bergeser. Dulu fotografi merupakan aktivitas yang hanya dapat dilakukan oleh segelintir orang saja karena biaya dan alat yang digunakan relatif mahal, tidak terjangkau, dan untuk dapat motret (mengoperasikan kamera) tidaklah mudah.

Namun, seiring dengan perkembangan teknologi (kamera digital), memotret kini menjadi relatif mudah dan semua orang dapat menjadi fotografer, baik itu sekadar hobi, dokumentasi, bahkan untuk dijadikan kegiatan yang lebih serius atau sebagai pekerjaan. Saat ini merupakan era yang masyarakatnya beranggapan bahwa memotret dapat dilakukan lebih mudah atau secara instan, ibaratnya tinggal pencet, gambar sudah jadi. Paradigma dan cara pandang tentang fotografi yang berubah juga berimbas pada dunia pendidikan, dalam hal ini di DKV. Untuk menguasai atau mempelajari topik tertentu yang dulu harus dilakukan beberapa kali pertemuan, sekarang sekali pertemuan sudah selesai. Yang dulu untuk melihat hasil foto harus menunggu beberapa hari, sekarang hanya diperlukan beberapa menit saja.

Menurut sumber Direktorat Akademik, Dirjen Dikti tahun 2008/2009, Perguruan Tinggi di Indonesia yang memiliki program studi Desain Komunikasi Visual (DKV) untuk program S-1 ada sebanyak 45 prodi, belum termasuk untuk jenjang D-1 dan D-3. Hingga saat ini (tahun 2017) dapat diperkirakan bahwa program S-1 DKV sudah lebih dari 50-an program studi di Indonesia. Jika dicermati pendidikan DKV tidak hanya ada di Peguruan tinggi saja, saat ini DKV juga ada dan berkembang pada tingkat/level sekolah menengah, yaitu Sekolah Menengah Kejuruan (SMK) yang mengalami perkembangan sangat cepat. Direktorat Pendidikan Menengah dan Kejuruan 
(Dikmenjur) Kemendiknas memang sangat progresif dalam mengembangkan sekolahsekolah kejuruan DKV. Jika tidak dibarengi dengan peningkatan kualitas, perluasan lapangan kerja, dan persebaran wilayah kerja akan menjadi masalah di kemudian hari. Jangan sampai terjadi tumpang tindih dalam memberikan pengajaran yang hampir sama sehingga nantinya lulusan S-1 harus bersaing dengan lulusan SMK yang memiliki minat DKV. Meskipun secara konsep pendidikan berbeda, namun pada kenyataannya banyak pendidikan S-1 yang seharusnya berbasis akademik justru lebih menekankan pada kemampuan praktis yang menjadi porsi dari jalur vokasi (program diploma dan SMK).

Ada beberapa pelajaran atau materi kuliah yang ada di SMK juga dipelajari di Perguruan Tinggi. Salah satunya adalah "fotografi". Di perguruan tinggi yang memiliki prodi DKV hampir dipastikan ada mata kuliah fotografi. Mata kuliah fotografi dalam kurikulum pada umumnya diberikan dalam 2 semester. Akan tetapi ada beberapa perguruan tinggi yang memberikan dalam 3, bahkan 4 semester. Penamaan mata kuliah "Fotografi" dalam kurikulum berbeda-beda, ada yang memberi nama Fotografi Dasar dan Fotografi Desain; Fotografi Dasar dan Fotografi Aplikatif, dan sebagainya. Namun, tidak sedikit materi kuliah Fotografi yang diajarkan di SMK dan perguruan tinggi relatif hampir sama. Mahasiswa lebih banyak dibekali hal-hal yang sifatnya praktik/ vokasi, tidak semua dibekali konsep dan pemikiran mengapa (why) tetapi bagaimana membuat (how to). Tujuan dari pendidikan tentunya ingin menciptakan sumber daya insani yang kompeten dan dapat memberikan kontribusi optimal pada industri/dunia kerja selaras dengan strata pendidikannya.

Tujuan dari penulisan ini adalah untuk memberikan gambaran tentang pentingnya mata kuliah Fotografi di Perguruan Tinggi yang dimiliki prodi DKV di Indonesia saat ini. Di samping itu, tulisan ini juga ingin menjawab pertanyaan bagaimana pendidikan DKV dapat memberikan berkontribusi pada industri DKV sekaligus turut memelihara profesi terkait DKV dalam suatu sinergi yang produktif.

\section{METODE}

Metode yang digunakan dalam penulisan ini adalah pendekatan kualitatif melalui kegiatan observasi, wawancara, dan studi literature untuk mendapatkan data pendukung serta mencari kerangka teori guna menguatkan hasil penulisan. Dari data dan kerangka teori yang diperoleh dilakukan analisis dengan membaca kondisi nyata di lapangan. Kajian ini didasari atas respon penulis selaku dosen DKV dan sekaligus asesor BAN-PT sejak 2006 dalam melihat fenomena yang ada di lapangan dan membaca secara langsung terjadinya perubahan mengenai cara pandang/paradigma di dalam pengajaran dan kurikulum yang diterapkan di program studi DKV khususnya untuk mata kuliah Fotografi.

\section{HASIL DAN PEMBAHASAN \\ Fotografi dari Konvensional ke Digital}

Sejarah fotografi diawali pada abad XIX oleh dua tokoh yang sangat terkenal yaitu Niepce dan Daguerre, keduanya dari negara Prancis. Tidak hanya sampai di sini saja, keduanya juga mampu mengembangkannya sesuai dengan prinsip-prinsip dasar fotografi, yakni kamera, lensa, bahan kimia, serta media pendukung lainnya.

Perkembangan fotografi selalu terjadi. Pada awalnya pengoperasian kamera dilakukan secara manual penuh (full manual), selanjutnya mengarah pada semi automatic dan full automatic. Misalnya pada tahun 1980-an muncul pengoperasian kamera dengan sistem autofocus, yang telah banyak membantu dan mengurangi kesulitan fotografer. Namun, meski telah banyak membantu kerja fotografer bukan berarti hasil foto langsung dapat dilihat karena masih ada proses yang harus dilalui, misalnya cuci film, proses cetak dan baru dapat dilihat hasilnya.

Tahun demi tahun perkembangan teknologi fotografi dan proses kimiawi semakin maju, pembuatan gambar dapat dipersingkat yang pada awalnya membutuhkan hitungan jam, ke menit, hingga kemudian hanya sampai memerlukan sepersekian detik. Kini di abad ke-21, teknologi fotografi yang telah sekian tahun diakrabi tibatiba dikejutkan dengan perkembangan dan 
penemuan foto digital. Fotografi mengalami perubahan/revolusi yang maha dahsyat. Banyak prinsip atau cara kerja lama yang berubah dan telah tergantikan dengan yang baru. Jelas lebih mudah. Dulu foto sebagai barang yang mahal dan eksklusif. Namun kini masyarakat menjadi sangat antusias dan interest terhadap fotografi, selain proses cepat, mengoperasikan mudah, biaya yang dikeluarkan pun relatif murah.

Awal tahun 1990-an menandai sebuah era baru di dunia fotografi, yaitu munculnya inovasi baru dengan adanya kamera digital. Dengan kamera digital banyak kemudahan yang diperoleh fotografer, antara lain pemrosesan film sudah tidak dilakukan lagi, karena media film telah digantikan media digital yang disimpan pada kartu memori. Di samping itu, hasil pemotretan langsung dapat dilihat sehingga ketika hasil tidak sesuai dapat langsung dipotret diulang. Pengoperasian kamera digital pada dasarnya relatif mudah dan sangat membantu fotografer atau para pemula yang berminat pada fotografi dibanding kamera analog/ konvensional. Era analog/konvensional sedikit demi sedikit ditinggal, karena era digital memungkinkan semua orang terlibat (dapat menggunakan).

Dengan digital, waktu tidak menjadi hambatan, lebih hemat, seluruh proses dapat kita kontrol, dari pengambilan gambar hingga pencetakan sepenuhnya berada di tangan fotografer. Dengan digital kita dapat memastikan hasilnya saat itu juga. Sesaat setelah gambar kita ambil, hasilnya dapat kita lihat lewat layar (LCD). Pengambilan gambar pun lebih mudah, mau berwarna atau hitam-putih tinggal pilih, pemilihan ISO pun lebih fleksibel dan dapat dirubah-rubah sesuai kondisi pemotretan. Dengan kamera digital memungkinkan kita untuk mengolah sendiri sesuai keinginan kita. Kamera digital menawarkan alternatif baru untuk sebuah proses foto yang dulu dikerjakan dalam kamar gelap, seperti dodging, burning, sandwich, bas relief, posterisasi, solarisasi, dan sebagainya kini dapat dikerjakan dengan cepat dan di ruangan terang dengan perangkat komputer.

Meski banyak yang dapat ditawarkan dari digital, bukan berarti fasilitas dan kemudahan digital akan menjamin dengan pasti bahwa akan selalu menghasilkan foto yang bagus. Foto bagus hanya akan dihasilkan dari pemotretan yang terencana dan diperlukan pemahaman tentang fotografi. Not just taking picture but making picture, artinya bahwa memotret bukan mengambil gambar, melainkan membuat gambar, karena kalau mengambil tidak ada usaha untuk menyusun, menata agar foto menarik, mengandung kesan. Membuat foto adalah cenderung berusaha menciptakan gambar semenarik mungkin dengan konsep yang jelas, menyusun rencana, dan mempertimbangkan berbagai hal. Secanggih apapun kamera yang digunakan, tetap saja kamera hanyalah sebuah alat. Manusia yang memegang kameralah yang harus berperan, bukan alat yang berperan pada kita.

Untuk menghasilkan foto yang bagus, tidak hanya sekadar punya kamera dan jepret saja, namun butuh pengetahuan tentang fotografi yang benar. Kamera analog atau digital pada dasarnya memiliki kesamaan prinsip dasar yang sama. Ciri pokok fotografi adalah ada cahaya, lensa, ruang kedap cahaya, dan film (media perekam lain, misalnya CCD atau Cmos). Digital fotografi telah mengambil alih apa yang dapat dilakukan oleh cara kerja fotografi analog/ konvensional dengan waktu yang cepat, biaya murah, dan mampu mewujudkan imajinasi yang tidak dapat dilakukan fotografi analog. Namun, kerja dengan analog atau digital yang penting harus memahami visi (vision), berpikir kreatif (thinking creative) dan memiliki keterampilan (skill) serta memahami elemen-elemen esensial pada fotografi (Souders, 2002: 114).

Perkembangan teknologi tidak dapat kita tolak dan hentikan, justru kita harus menyikapi dengan bijak, mengingat masyarakat saat ini yang semakin instant-minded secara otomatis akan mengidentifikasikan dirinya dengan alat-alat atau kamera yang dapat bekerja dengan cepat, mudah pengoperasiannya, murah, dan hasilnya baik. Gejala budaya visual yang tercermin pada media komunikasi memang sangat dominan berkembang di masyarakat. Berkembangnya budaya visual ini bakal ditopang alat pencitraan yang salah satunya kamera digital, yang kini mulai dan telah diakrabi oleh masyarakat. 


\section{Fotografi dan Dunia Industri}

Setiap ada kemajuan dan perkembangan dari sebuah teknologi, secara pasti juga ada perubahan sikap dan konsekuensi yang harus diikuti. Hal ini juga berlaku bagi mereka yang berkecimpung pada dunia fotografi. Demikian pula dunia industri/perusahaan yang memanfaatkan karya fotografi, mereka juga menuntut suatu perubahan dalam cara kerja fotografer. Karya foto banyak dibutuhkan pada industri, perusahaan atau lembaga tertentu (penerbit, percetakan, periklanan, biro disain, dan lain-lain) untuk menunjang dalam menyampaikan pesan-pesannya baik komersial/ non-komersial, misalnya sebagai ilustrasi atau elemen dalam bentuk media cetak seperti folder, leaflet, brosur, iklan koran, iklan majalah, kalender, poster, dan lain-lain. Fotografi sebagai salah satu elemen dalam disain komunikasi visual yang tampil secara realistis, cepat prosesnya, mampu meyakinkan komunikan/ konsumen, sehingga menjadi pilihan yang sangat tepat bagi industri/perusahaan dalam menawarkan barang/jasanya.

Perkembangan fotografi/kamera digital sudah diprediksi akan mendapat perhatian dan sangat berpengaruh pada bidang industri, seperti penerbitan dan percetakan, periklanan/ biro desain grafis, dan bidang-bidang bisnis fotografi. Seperti dikatakan Mr. Kasai dari Jepang, bahwa hadirnya kamera digital akan mengalami perubahan besar di Indonesia, dan akan membawa perubahan besar terhadap proses kerja di bidang industri, dan kamera digital juga akan menjadi tumpuan bagi pengusaha di bidang fotografi (Fotomodern, No. 5, Sept 1995:13).

Sebelum ada kamera digital untuk membuat foto manusia terbang, manusia bersayap, imajinasi yang aneh-aneh sangat sulit bahkan tidak mungkin dilakukan. Namun di era digital, ide apapun dapat diwujudkan/relatif dapat dibuat. Teknik-teknik yang dulu sulit dipelajari dan lama prosesnya, seperti multiprint, multi exposed, sandwich, solarisasi dan lainnya. Sekarang, dengan menguasai teknologi yang berbasis digital, dengan mudah dan cepat dapat diciptakan.
Iswanto, fotografer profesional mengatakan bahwa, "Paradigama tentang fotografi sekarang ini mulai bergeser dan harus dipahami dan diikuti, kalau masih ingin eksis sebagai fotografer harus mengikuti perubahan ini, kalau tidak mengikuti lambat laun akan tersingkir." Di era digital sekarang ini, seorang fotografer tidak hanya dapat menguasai kamera, lighting dan teknis fotografi saja, namun dituntut juga memiliki wawasan dan pengetahuan dan menguasai teknologi digital. Seorang fotografer yang belum menguasai perangkat fotografi digital (kamera, komputer, photoshop, printer, dan sebagainya), dalam kerjanya paling tidak perlu didampingi seorang digital artist. Karena saat ini klien (biro iklan, advertising) tidak mau menerima foto berupa print (foto cetakan), namun foto yang sudah siap didesain yang berupa soft copy (data digital). Kerja sama tim antara fotografer dan digital artist sekarang ini mutlak diperlukan karena sebuah foto jadi/final prosesnya dapat terdiri dari beberapa pemotretan yang dilakukan, dapat beda lokasi, beda angle of view, beda setting, dan lainnya. Artinya tim ini perlu tahu mana gambar yang diperlukan, mana yang harus dibuang/di-crop, mana yang dapat edit/retouch, dan sebagainya. Maka akan lebih ideal jika seorang fotografer selain memiliki ide yang baik, dapat menguasai kamera, teknik fotografi, lighting dan estetika yang baik, juga menguasai perangkat lain seperti komputer serta software yang diperlukan, sehingga dapat mewujudkan/memvisualkan gagasan/ide dari klien (art director) dengan baik.

Herdamon dalam fotomedia (2005: 12) mengatakan bahwa seorang fotografer yang baik pada umumnya:

1. memiliki gagasan/ide yang baik dan unik,

2. mampu menuangkan ide/gagasan dalam bentuk visual/foto,

3. menguasai peralatan fotografi,

4. memahami dan menguasai teknik-teknik fotografi, dan

5. memiliki taste/cita rasa seni.

Selain hal-hal tersebut di atas, wawasan dan pengetahuan yang luas berkaitan dengan berkembangnya teknologi sangat dibutuhkan dan harus diikuti perkembangannya. Seperti 
dikatakan Sam Nugroho, bahwa perkembangan beberapa tahun ke depan dapat lebih dahsyat lagi yakni berbaurnya antara Digital imaging, 3D, dan fotografi (concept :13) karena ketiga unsur tersebut sangat dekat dan saling berkaitan antara satu dengan yang lain. Lebih lagi pengguna komputer sudah banyak dan tidak asing bagi masyarakat dewasa ini, sehingga masyarakat pengguna komputer menuntut dirinya juga dapat memotret, menyinpan, mengolah dan mencetaknya. Paradigma fotografi yang dulu relatif susah dilakukan, sekarang di era kamera digital, masyarakat memandang fotografi sebagai sesuatu yang mudah, murah, dan merupakan bagian dari kehidupan sehari-hari, inilah era digital photography.

\section{Fotografi dalam Dunia Pendidikan di DKV}

Peran Penting dan Pengajaran Fotografi di DKV

Istilah Desain Komunikasi Visual atau lebih akrab dengan sebutan DKV sekarang sudah tidak asing lagi di telinga, karena sudah banyak perguruan tinggi/lembaga pendidikan memiliki program studi/jurusan DKV. Out put/lulusan dari prodi ini diyakini memiliki prospek kerja/profesi yang banyak dibutuhkan dalam masyarakat atau terserap di dunia industri. Selama industri ada dan berkembang, lulusan DKV pasti diperlukan. Pada umumnya S-1 DKV memiliki 144-148 sks dan memiliki matakuliah Fotografi dengan bobot 5-8 sks. Di antara mata kuliah penting yang lain, ada mata kuliah Fotografi yang sangat strategis dan penting. Dalam DKV menu mata kuliah yang harus ada adalah fotografi, ini dianggap strategis dan penting artinya bahwa dalam DKV elemen visual ini sering dimanfaatkan untuk berbagai perancangan desain.

Mata kuliah Fotografi biasa diajarkan/ diberikan secara bervariasi di setiap perguruan tinggi, ada yang selama tiga semester, yakni Fotografi I, Fotografi II, dan Fotografi Desain. Fotografi I memberikan materin tentang pengetahuan fotografi serta penguasaan peralatan fotografi dan teknik-teknik pemotretan, lighting, dan lainnya. Fotografi I ini merupakan dasar dan sebagai bekal awal yang harus dipahami dan dikuasai. Fotografi II memberikan materi tentang seluk beluk mengaplikasikan karya foto untuk kebutuhan disain grafis (DKV) misalnya foto ilustrasi, foto land mark, essai dan lain-lain. Selain materi tersebut juga diberikan pengetahuan olah visual/kamar gelap, eksperimen-eksperimen yang berkaitan dengan fotografi. Pada mata kuliah Fotografi Desain mahasiswa diberikan cara/teknis pemotretan di studio secara profesional, baik pemotretan still life atau manusia. Pembuatan foto diarahkan untuk kepentingan DKV (cenderung komersial), juga diajari membuat konsep dan riset hingga aplikasinya ke dalam media.

Namun demikian, ada beberapa perguruan tinggi yang membagi mata kuliah Fotografi menjadi dua (2) dengan memberi nama: Fotografi Dasar dan Fotografi Desain; Fotografi 1 dan Fotografi 2; Dasar-dasar Fotografi dan Fotografi Aplikatif, dan lain-lain. Dengan bekal fotografi dua semester, tiga semester atau lebih dan memberikan materi yang disesuaikan dengan kebutuhan DKV dan perkembangan teknologi saat ini, diharapkan mahasiswa memiliki kemampuan menciptakan foto yang baik dan menarik, komunikatif untuk kepentingan komersial maupun non-komersial.

Selain memiliki dan menguasai hal di atas, seorang fotografer perlu juga memiliki kesadaran untuk melakukan penelitian/riset sebelum melakukan pemotretan. Dengan riset sangat banyak manfaat yang diperoleh bagi fotografer maupun bagi pihak-pihak yang berkepentingan dengan foto tersebut. Selain mendapatkan hasil foto yang baik, menarik, indah, dan lain sebagainya, pekerjaan pun akan lebih efektif dan efisien. Karena riset adalah bagian dari tujuan fotografer dalam melakukan pemotretan. Bagaimanapun sederhananya tujuan dalam pemotretan, riset sangat diperlukan. Riset dalam fotografi baik dari sisi ide/gagasan, teknis, estetis dapat meliputi identifikasi permasalahan, menganalisis, mengambil kesimpulan hingga sampai pada suatu eksekusi atau pelaksanaan pemotretan.

Ketika seseorang mengatakan riset, gambaran yang muncul adalah laboratorium yang lengkap dengan peralatan-peralatan yang serba canggih, prosedural, dan rumit. 
Istilah riset selama ini selalu dihubungkan dengan sesuatu yang rumit, ilmiah, disiplin, kaku, dan berbau akademis. Istilah riset menurut Kamus Besar Bahasa Indonesia adalah penyelidikan (penelitian) suatu masalah secara sistematis, kritis, dan ilmiah untuk meningkatkan pengetahuan dan pengertian, mendapatkan fakta baru, atau melakukan penafsiran yang lebih baik (Depdikbud, 1998:844). Meskipun pada umumnya istilah riset ini sering dilakukan oleh suatu lembaga, perusahaan, maupun institusiinstitusi sebelum melakukan pekerjaannya, namun secara tidak disadari seorang fotografer sebelum melakukan pemotretan perlu dan penting melakukan riset/penelitian.

Melakukan riset berarti menyiapkan diri untuk melakukan penyelidikan atau mendapatkan fakta yang baru, artinya riset sudah bukan hal baru bagi fotografer. Karena riset yang dilakukan fotografer tidak harus dikaitkan dengan bidangnya para peneliti atau ilmuwan. Contohnya adalah dalam foto jurnalistik yang menuntut kriteria informatif, aktual, faktual, terpercaya, dan otentik, riset seharusnya sudah menjadi sesuatu hal yang wajib para fotografer. Karena fotonya harus tampil dengan 'kedalaman' yang mewakili sebuah fakta. Demikian pula halnya dengan foto komersial (barang/jasa) yang menuntut penampilan akan daya tarik visual yang informatif dan persuasif. Dengan demikian, untuk membuat foto apapun kepentingannya idealnya riset atau penelitan sangat diperlukan.

Secara sederhana fotografer akan menghadapi persoalan-persoalan seperti dari mana sudut pengambilan yang paling baik, dengan lensa berapa, diafragma berapa, kecepatan berapa, diambil keseluruhan atau dipotong, dan seterusnya. Artinya, memotret (fotografi) adalah pekerjaan ilmiah, karena membuat foto tidak hanya sekadar persoalan teknis melainkan mencari suatu pemecahan atas persoalan yang harus dapat diatasi dan diuraikan secara sistematis. Oleh karena itu, sebelum melakukan pemotretan fotografer perlu terlebih dulu melakukan penelitian/riset tentang objek atau subjek yang akan dibuat agar fotonya tersaji dengan baik dan mampu menjawab permasalahannya. Menurut Kountur (2003: 3-8) penelitian/riset berhubungan dengan usaha untuk mengetahui sesuatu, mencari suatu jawaban atas suatu permasalahan.

Pada dasarnya dikenal dua cara untuk memecahkan persoalan yaitu secara rasional dan empiris. Pendekatan secara rasional (internal process) di mana untuk memecahkan suatu persoalan dimulai dari suatu gagasan atau ide yang dimiliki sesorang. Sedangkan pendekatan empiris (external process), di mana jawaban atas persoalan ada pada objek di mana masalah tersebut berada, dan yang harus dilakukan adalah mengidentifikasi, mengamati, observasi, mencari data, dan membuat suatu kesimpulan.

Dengan melihat begitu banyak kebutuhan foto yang dapat dimanfaatkan untuk kepentingan pada media komunikasi visual, maka sudah selayaknya mata kuliah fotografi di DKV perlu mendapatkan perhatian dari semua pihak (mahasiswa dan lembaga). Meskipun di atas ada pembagian profesi/konsentrasi fotografer, namun tujuan pengajaran fotografi di DKV tidak mengarah pada satu profesi atau spesialisasi. Pembuatan foto atau pemotretan yang dilakukan mahasiswa di prodi DKV lebih menekankan pada tujuan utama bahwa foto sebagai karya komunikasi visual dan dapat difungsikan untuk kepentingan disain komunikasi visual.

Fotografi bagi DKV adalah hal yang sangat penting dan dibutuhkan sebagai salah satu elemen visual. Seperti pada media cetak, misalnya untuk kalender, brosur, leaflet, iklan koran, iklan majalah, poster dan banyak lagi, hal tersebut dapat kita lihat dan cermati dari media komunikasi visual yang ada di lapangan, baik yang berbentuk media cetak peran foto masih dominan. Seperti dikatakan Lady Elisabet dalam tulisan Suprapto Sujono (2006:14), bahwa fotografi merupakan 'medium komunikasi'. Dalam hal ini sebuah karya fotografi dimanfaatkan dalam DKV/disain grafis sebagai elemen ilustrasi dalam media cetak seperti iklan cetak karena reliability dalam tampilannya dan dapat meyakinkan konsumen/komunikan. Penampilan ilustrasi dengan fotografi yang tampil secara realistik (sesuai produk; sesuai kenyataan) tentu akan 
lebih meyakinkan dan memiliki nilai persuasif untuk mempengaruhi konsumen. Dengan kata lain karya fotografi lebih komunikatif secara visual.

Dengan melihat kenyataan di lapangan, dan pendapat tersebut sudah barang tentu bahwa mata kuliah fotografi sangat diperlukan untuk mahasiswa DKV. Namun dengan perkembangan teknologi fotografi sekarang ini, perlu ada evaluasi dan perubahan dalam pengajaran fotografi. Yang perlu menjadi perhatian, bagi perguruan tinggi yang masih memiliki program/ jurusan ataupun mata kuliah fotografi perlu mengevaluasi materi ataupun kurikulum lama yang sudah puluhan tahun digunakan agar ditinjau ulang sesuai perkembangan fotografi. Dengan hadirnya teknologi digital, termasuk kamera digital yang berkembang dengan pesat seperti sekarang ini, sangat memungkinkan bergesernya pandangan atau paradigma tentang fotografi.

\section{Dasar Seni Rupa Penting untuk Fotografer}

Tidak heran apabila sekarang ini hampir setiap orang dapat mengoperasikan kamera, bahkan anak kecil pun sudah dapat motret. Perlu disadari bahwa memotret tidak sekadar mengambil gambar, melainkan membuat gambar, artinya untuk mendapatkan sebuah foto/gambar yang baik banyak hal yang perlu dipelajari, misalnya dari segi teknis fotografi, lighting, pengetahuan estetika/seni rupa atau memiliki pengetahuan seni visual yang baik. Kalau kita bicara mengenai fotografi, tidak hanya pada yang serba teknis saja, namun banyak hal di luar masalah teknis. Dikatakan Soeprapto Soedjono bahwa, fotografi sebagai salah satu entitas dalam domain seni rupa tidak dapat terlepas dari nilai-nilai dan kaidah-kaidah seni rupa (2006:7). Dengan kata lain meskipun peralatan yang tersedia sangat canggih, selain diperlukan kemampuan teknis juga kemampuan estetis yang memadai. Jam terbang yang tinggi dan dengan banyak membaca dan melihat buku fotografi, masalah teknis fotografi dapat diatasi, tetapi hal yang berkaitan seni rupa, rasa estetika yang baik, tidak dapat dicapai dengan membaca dan melihat saja, melainkan harus dengan melakukan/praktik.
Dengan melakukan praktik psikomotorik misalnya menggores (olah visual seperti melukis, nirmana, menggambar, sketsa), artinya kita memindahkan objek yang tiga dimensi ke bentuk dua dimensi, dengan latihan ini kita belajar melihat dan merasakan bentuk, sinar, bayangan, gradasi, warna, pola maupun tekstur. Perlu diketahui bahwa fotografi adalah seni melihat (the art of seeing), dasar ilmu melihat ini berlaku untuk ilmu pengetahuan lain termasuk fotografi. Demikian pula halnya yang terjadi dalam membuat gambar/foto, berawal dari melihat/mata. Dasar seni rupa seperti menggambar, nirmana, anatomi, sejarah seni rupa bahkan kritik seni sangat penting sebagai bekal untuk belajar fotografi (Zahar, 2003: 101). Karena prinsip fotografi tidak jauh dengan menggambar, artinya menggambar sama dengan memotret, seperti kata fotografi sendiri berasal dari kata photos (cahaya) dan graphos (menggambar/menggores) artinya menggambar dengan cahaya.

Dengan melihat dan menyadari arti pentingnya melakukan aktivitas psikomotorik dengan menggambar, merancang nirmana, dan memahami wawasan seni rupa, merupakan salah satu bekal untuk dapat membuat foto yang baik. Dengan demikian, sudah seharusnya mahasiswa/ kita yang belajar fotografi lebih cepat menguasai dan lebih baik dibanding yang hanya belajar teknis fotografi saja.

\section{KESIMPULAN}

Pasca tahun 1990-an DKV mulai memasuki era teknologi digital yang merubah budaya kerja di industri ini. Dari ketergantungan dengan kemampuan skill manual manusia berubah menjadi serba komputerisasi. Semua keahlian tersebut dapat digantikan oleh piranti lunak dan piranti keras komputer. Hal ini merupakan salah satu yang merubah paradigma Perguruan Tinggi DKV lebih berkembang ke arah digitalisasi. Di Indonesia saat ini Perguruan Tinggi DKV juga lebih menitikberatkan pada penguasaan aplikasi komputer grafis. Pertumbuhan pendidikan DKV yang pesat juga tidak lepas dari perkembangan teknologi dan media informasi. Fenomena ini membuka peluang tumbuhnya profesi-profesi 
baru terkait dengan DKV yang pada akhirnya meningkatkan permintaan akan jasa pendidikan DKV.

DKV sebagai "seni komunikasi" secara visual pada dasarnya lebih dekat dengan bidang seni rupa, meskipun demikian secara profesi DKV merupakan perpaduan dari berbagai disiplin ilmu/keahlian yang digunakan untuk menjawab kebutuhan komunikasi dan informasi, baik komersial dan non komersial. Salah satu bidang keahlian DKV yang perlu dipelajari adalah fotografi. Pengetahuan dan keterampilan fotografi sangat penting dan sangat berguna sebagai bekal mahasiswa DKV yang dapat diterapkan saat masih menempuh kuliah maupun setelah selesai studi/lulus. Pengetahuan dan keterampilan fotografi yang diajarkan di S-1, yang notabenenya akademis, sebaiknya tidak sekadar bagaimana dapat mengoperasikan peralatan kamera dan menggunakan peralatan yang lain (how to), akan tetapi juga sangat penting meningkatkan pengetahuan dan keterampilan yang sifatnya konseptual dan riset terkait kegiatan fotografi. Artinya bahwa fotografi adalah pekerjaan ilmiah (akademis), karena membuat foto tidak hanya sekadar teknis melainkan mencari suatu pemecahan atas persoalan yang harus dapat diatasi dan diuraikan secara sistematis. Oleh karena itu, sebelum melakukan pemotretan fotografer perlu terlebih dulu melakukan penelitian/riset tentang objek atau subjek yang akan dibuat agar fotonya tersaji dengan baik dan mampu menjawab permasalahannya. Komposisi mata kuliah fotografi di DKV untuk S1 yang memiliki beban 5-8 sks dari keseluruhan 144148 sks harus dimanfaatkan secara maksimal untuk bekal mahasiswa.

Di era kamera digital, masyarakat memandang fotografi sebagai sesuatu yang mudah, murah, dan merupakan bagian dari kehidupan sehari-hari, dan inilah era digital photography (digitalisasi fotografi). Meskipun peralatan fotografi saat ini sangat canggih namun masih tetap diperlukan seseorang yang memiliki kemampuan teknis dengan kepekaan estetis yang baik sebagai 'man behind the camera' dalam menciptakan fotografi. Artinya keterampilan dan pengetahuan seni rupa seperti menggambar, nirmana, kritik/tinjauan seni, sejarah sangat penting sebagai landasan mengasah kepekaan dan konseptual dalam menciptakan karya foto.

\section{DAFTAR PUSTAKA}

Ajidarma, Seno Gumira. (2002). Kisah Mata Fotografi antara Dua Subyek: Perbincangan tentang Ada. Yogyakarta: Galang Press.

Budiman, Andi S., (2006). “Akan Jadi Kebutuhan Sehari-hari". Concept - majalah desain grafis, edisi 14.

Griand, Giwanda. (2004), Panduan Praktis Teknik Studio Foto. Jakarta: Puspa Swwara.

Kasai, Akira.(1995). "Dampak Fotografi Digital terhadap Dunia Cetak Mencetak", Foto Modern, No. 5, Edisi September.

Pemerintah Republik Indonesia. (2003) UndangUndang No. 20 Tahun 2003 Tentang Sistem Pendidikan Nasional.

Pemerintah Republik Indonesia. (2010). Peraturan Pemerintah No. 17 Tahun 2010 Tentang Pengelolaan dan Penyelengaraan Pendidikan.

Souders, Rick. (2002). The Art and Attitude of Commercial Photography. New York: Watson-Guptill Publications.

Soejono, Soeprapto. (2006). Pot-Pourri Fotografi. Jakarta: Penerbit Universitas Trisakti.

Soerjanto, Iswanto. (1996). "Diasah untuk Siap". Fotomedia, edisi Agustus.

Zahar, Iwan. (2003). Catatan Fotografer Kiat Jitu Menembus New York. Jakarta: Creative Media. 